\title{
Removal of cadmium(II) and lead(II) ions from model aqueous solutions using sol-gel-derived inorganic oxide adsorbent
}

\author{
Filip Ciesielczyk $^{1} \cdot$ Przemysław Bartczak $^{1} \cdot$ Teofil Jesionowski $^{1}$
}

Received: 17 August 2015/Revised: 23 September 2015/Accepted: 8 October 2015/Published online: 20 October 2015

(C) The Author(s) 2015. This article is published with open access at Springerlink.com

\begin{abstract}
A study was conducted concerning the preparation and application of a novel synthetic oxide adsorbent of $\mathrm{MgO}-\mathrm{SiO}_{2}$ type. The material was prepared via a sol-gel route, utilizing magnesium ethoxide and tetraethoxysilane as precursors of magnesium oxide and silica respectively, and ammonia as a catalyst. The powder was comprehensively analyzed with regard to chemical composition (EDS method), crystalline structure, morphology, characteristic functional groups, electrokinetic stability and porous structure parameters (BET and BJH models). The synthesized oxide adsorbent is amorphous, with irregularly shaped particles, a relatively large surface area of $612 \mathrm{~m}^{2} / \mathrm{g}$, and negative surface charge over almost the whole $\mathrm{pH}$ range. Comprehensive adsorption studies were performed to investigate the adsorption of $\mathrm{Cd}$ (II) and $\mathrm{Pb}$ (II) ions on the $\mathrm{MgO}-\mathrm{SiO}_{2}$ oxide adsorbent, including evaluation of adsorption kinetics and isotherms, the effect of $\mathrm{pH}$, contact time and mass of adsorbent. It was shown that irrespective of the conditions of the adsorption process, the synthesized $\mathrm{MgO}-\mathrm{SiO}_{2}$ adsorbent exhibits slightly better affinity to lead(II) than to cadmium(II) ions (sorption capacity of $102.02 \mathrm{mg}\left(\mathrm{Pb}^{2+}\right) / \mathrm{g}$ and $\left.94.05 \mathrm{mg}\left(\mathrm{Cd}^{2+}\right) / \mathrm{g}\right)$. The optimal time for removal of the analyzed metal ions was $60 \mathrm{~min}$, although adsorption reached equilibrium within $10 \mathrm{~min}$ for $\mathrm{Pb}$ (II) and within $15 \mathrm{~min}$ for $\mathrm{Cd}$ (II) ions, which was found to fit well with a type 1 pseudo-second-order kinetic model. Additionally, adsorption efficiency was affected by the $\mathrm{pH}$
\end{abstract}

Filip Ciesielczyk

Filip.Ciesielczyk@put.poznan.pl

1 Faculty of Chemical Technology, Institute of Chemical Technology and Engineering, Poznan University of Technology, Berdychowo 4, 60965 Poznan, Poland of the reaction system-better results were obtained for $\mathrm{pH}$ $\geq 7$ irrespective of the type of metal ion.

Keywords Sol-gel route $\cdot$ Oxide adsorbents $\cdot$ Cd(II) and $\mathrm{Pb}(\mathrm{II})$ ions $\cdot$ Adsorption kinetics

\section{Introduction}

Industrial development and ongoing urbanization continue to bring about growing problems related to waste production. Wastes are a source of toxic substances which migrate unhindered through the natural environment, causing its degradation, and at the same time having an adverse effect on living organisms, including humans. One of the most dangerous groups of inorganic pollutants is the heavy metals, including among others cadmium, lead, nickel and mercury (Shafique et al. 2011).

Adsorption is one of the highly selective methods for removing heavy metals from aqueous solutions (Gupta and Bhattacharyya 2012, 2014; Khan et al. 2013). This is an economical technique which also offers numerous advantages resulting from the vast number of available adsorbents (Barakat and Kumar 2015; Ezzeddine et al. 2015; Lee et al. 2015; Li et al. 2015; Peng et al. 2015). With the development of modern technologies, a very wide range of materials have come to be used as hazardous metal adsorbents, from natural substances to highly selective synthetic systems (Cutillas-Barreiro et al. 2014; Kołodynska et al. 2012; Santhosh et al. 2015; Wysokowski et al. 2014). Alongside precipitation and hydro- or solvothermal methods, one of the basic techniques used for the synthesis of a wide range of synthetic, inorganic and inorganic/ organic hybrid adsorbents is the sol-gel method (Hassan et al. 2014; Motlagh et al. 2015). Because of the 
mechanism of this process, it is made possible to define the physicochemical properties of materials of this type, including especially their porous structure parameters, which are extremely important for environmental applications (Fan et al. 2014a, b, c; Sriprang et al. 2014; Viltuznik et al. 2015). Both, natural and synthetic adsorbents can be modified so as to enhance their most important properties, such as surface area (Karthik and Meenakshi 2015a, b; Klapiszewski et al. 2015; Zhao et al. 2014). In many cases, simply changing the process for preparation an adsorbent or the method of modifying it may lead to an increase in its sorption capacity with respect to a specific group of pollutants (Borhade et al. 2015; Guo et al. 2014; Madrakian et al. 2014; Nguyen et al. 2015).

Much attention is also paid to the appropriate design of the adsorption process, which entails the need to carry out numerous laboratory studies with the aim of optimizing the time of contact between adsorbent and adsorbate, the $\mathrm{pH}$, or the temperature (Dubey et al. 2009; Kowalczyk et al. 2013; Li et al. 2010; Mortaheb et al. 2010; Song et al. 2011). Depending on the adsorptive material itself, and also on the adsorbate, a system requires specific conditions in which the most favorable results for adsorption efficiency can be obtained.

In the literature there is very little information regarding sol-gel derived $\mathrm{MgO}-\mathrm{SiO}_{2}$ adsorbent. Therefore, in this study, an attempt was made to apply the sol-gel route for synthesis of novel, active oxide adsorbent dedicated to the removal of hazardous metal ions from aqueous solutions. The adsorbent was analyzed in detail, particularly in terms of its porous structure parameters. As compared to other adsorbents obtained via traditional methods of water or emulsion precipitation, mechanism of sol-gel route allowed to synthesize material characterized with high purity, low bulk density and definitely improved parameters of the porous structure, including well developed surface area. Numerous sorption tests were performed, including evaluation of $\mathrm{pH}$ and temperature as well as sorption kinetics and isotherms.

\section{Experimental}

\subsection{Materials and methods}

\subsubsection{Preparation and characterization of $\mathrm{Mg}-\mathrm{Si}$ hybrid oxide adsorbent}

An inorganic oxide adsorbent of $\mathrm{MgO}-\mathrm{SiO}_{2}$ type was obtained via a modified sol-gel route using the organic magnesium precursor magnesium ethoxide, as described previously (Ciesielczyk et al. 2014). The synthesis was performed using a reactor $2 \mathrm{~L}$ in capacity, equipped with a heating jacket and high-speed anchor stirrer. At the first stage, a specified amount (45 g) of magnesium ethoxide was dissolved in $1500 \mathrm{~mL}$ of methyl alcohol. The whole system was stirred for $15 \mathrm{~min}$, and after that time tetraethoxysilane (the organic silica precursor) and the catalyst of hydrolysis (25\% ammonia solution) were introduced into it simultaneously. The quantities of the reactants were selected to achieve a TEOS:magnesium ethoxide mass ratio of 1.5:1. The mixture was additionally stirred for $60 \mathrm{~min}$ with a stirrer speed of $300 \mathrm{rpm}$. The alcogel obtained was placed in a crystallizer to enable solvent evaporation, and was then dried at $105^{\circ} \mathrm{C}$ for $48 \mathrm{~h}$. The dry oxide adsorbent was classified and comprehensively analyzed. The synthesis scheme is presented in Fig. 1. The chemical composition of the synthetic powder material (content of $\mathrm{Mg}, \mathrm{Si}$ and $\mathrm{O}$ ) was analyzed using energy dispersive X-ray spectroscopy (EDS), with the use of a Princeton Gamma-Tech unit with a prism digital spectrometer. The crystalline structure of the $\mathrm{MgO}-\mathrm{SiO}_{2}$ adsorbent was determined using the WAXS method. Diffraction patterns were taken using a TUR-M62 horizontal diffractometer equipped with an HZG-3 type goniometer over a $2 \theta$ range of $5^{\circ}-80^{\circ}$. The morphology and microstructure of the adsorbent were analyzed using a Zeiss EVO40 scanning electron microscope. The observations enabled evaluation of the degree of dispersion, the structure of particles and their tendency towards aggregation or agglomeration. The surface area $A_{B E T}$ (BET method) as well as pore volume and diameter (BJH method) were calculated based on data from measurements of low-temperature adsorption of nitrogen. The isotherms of nitrogen adsorption/desorption were computed at -196 ${ }^{\circ} \mathrm{C}$ using an ASAP 2020 apparatus (Micromeritics Instrument Co.). The FTIR spectrum was obtained using a Vertex 70 spectrophotometer (Bruker). The samples were analyzed in the form of tablets, made by pressing a mixture of anhydrous $\mathrm{KBr}$ (ca. $0.25 \mathrm{~g}$ ) and $1 \mathrm{mg}$ of the tested substance in a special steel ring, under a pressure of $10 \mathrm{MPa}$. Analysis was performed over a wavenumber range of $4000-400 \mathrm{~cm}^{-1}$ (at a resolution of $0.5 \mathrm{~cm}^{-1}$; number of scans: 64). Additionally, to evaluate the surface charge of the synthetic powder, the zeta potential was determined as a function of $\mathrm{pH}$. Electrokinetic studies were performed in $0.001 \mathrm{M} \mathrm{NaCl}$ electrolyte using a Zeta Nano ZS instrument (Malvern Instruments Ltd.) equipped with an MPT-2 automatic titration system.

As a result of this process, an inorganic oxide adsorbent characterized by irregularly shaped particles, amorphous structure and mesoporous nature, with a high BET surface area, was obtained. Moreover, the synthesized adsorbent has negative surface charge over the whole $\mathrm{pH}$ range. 


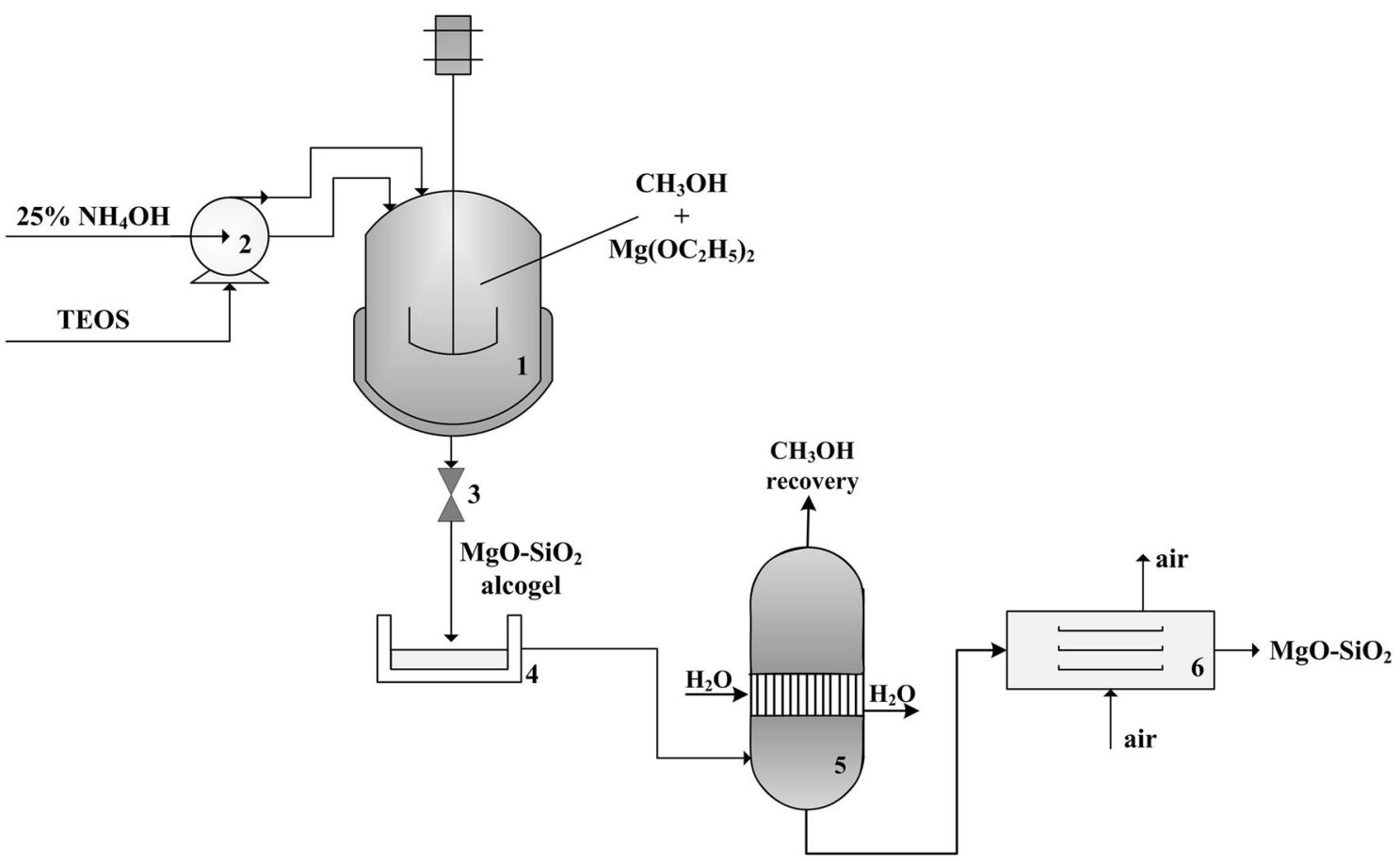

Fig. 1 Synthesis of $\mathrm{MgO}-\mathrm{SiO}_{2}$ inorganic oxide adsorbent via the sol-gel route ( 1 reactor with heating jacket, 2 pump, 3 valve, 4 crystallizer, 5 vacuum evaporator, 6 dryer)

\subsubsection{Sorption experiments}

Sorption experiments were conducted to investigate the adsorption of $\mathrm{Cd}(\mathrm{II})$ and $\mathrm{Pb}(\mathrm{II})$ ions on the inorganic oxide adsorbent of $\mathrm{MgO}-\mathrm{SiO}_{2}$ type. All sorption experiments were carried out in $250 \mathrm{~mL}$ flasks, to which an appropriate amount of adsorbent and $100 \mathrm{~mL}$ of the appropriate ion solution were added. Two different metal salts with the same competitive anions $\left(\mathrm{Cd}\left(\mathrm{NO}_{3}\right)_{2} \cdot 4 \mathrm{H}_{2} \mathrm{O}\right.$ and $\left.\mathrm{Pb}\left(\mathrm{NO}_{3}\right)_{2}\right)$ were used as metal ion precursors. This made it possible to evaluate the effectiveness of adsorption of different ions. The mixture was next stirred at $200 \mathrm{rpm}$ using a magnetic stirrer (RO10, IKA Werke) for 1-240 min. Sorption behavior, including contact time, mass of adsorbent, effect of $\mathrm{pH}$ and sorption kinetics, was investigated in detail. To evaluate the $\mathrm{pH}$ effect, measurements were performed with the initial $\mathrm{pH}$ of the solution ranging from 1 to 9 , and with the initial metal ion concentration in the range $25-100 \mathrm{mg} / \mathrm{L}$. To obtain the desired $\mathrm{pH}$, as monitored using a $\mathrm{pH}$-meter (Lab 850 , Schott Instruments), sodium hydroxide or nitric acid, in $0.1 \mathrm{M}$ solution, was added. In order to establish the optimal mass of the adsorbent (1-20 g/L) the experiment was performed over $60 \mathrm{~min}$ utilizing model solutions of appropriate metal ions in an initial concentration of $50 \mathrm{mg} / \mathrm{L}$. In the investigation of adsorption kinetics, metal ion solutions with initial concentrations of $25-100 \mathrm{mg} / \mathrm{L}$ and $\mathrm{pH} 5$ were used, in a quantity of $100 \mathrm{~mL}$. After adsorption, the adsorbent was separated by filtration, and the final concentration of ions in the solution was determined. To determine the stability of bonds between the adsorbate and the adsorbent, and to determine the effectiveness of removal of $\mathrm{Cd}(\mathrm{II})$ or $\mathrm{Pb}$ (II) ions from the surface of the adsorbent, elution tests with $\mathrm{H}_{2} \mathrm{O}$ were performed. AAS analysis was performed to evaluate the quantity of $\mathrm{Cd}(\mathrm{II})$ or $\mathrm{Pb}$ (II) ions present in the filtrate after the adsorption process and elution tests. The measurements were carried out to an accuracy of $\pm 0.1 \mathrm{mg} / \mathrm{L}$ using a Z-8200 spectrometer (Hitachi). Before the analysis, a calibration curve was prepared to enable calculation of the $\mathrm{Cd}(\mathrm{II})$ and $\mathrm{Pb}$ (II) ion concentrations in the filtrate. Additionally, the adsorbents underwent EDS analysis following the process, to evaluate the presence of $\mathrm{Cd}(\mathrm{II})$ and $\mathrm{Pb}(\mathrm{II})$ in their structure.

Determination of the adsorption kinetics of the studied metal ions was an important part of the experiments. Calculations were performed to determine the value $q_{t}$, which is needed to define various kinetic models: pseudo-firstorder (Lagergren 1898) and pseudo-second-order (Ho and McKay 1999). The quantity of metal ions adsorbed per unit time $\left(q_{t}\right)$ on the adsorbent surface was computed using Eq. (1):

$q_{t}=\frac{\left(C_{0}-C_{t}\right) \cdot V}{m}$

where $C_{O}$ and $C_{t}$ are the concentrations of cadmium(II) or lead(II) ions in the solution before and after sorption respectively $(\mathrm{mg} / \mathrm{L}), V$ is the volume of the solution $(\mathrm{L})$, and $m$ is the mass of sol-gel derived adsorbent $(\mathrm{g})$. 
Table 1 Physicochemical characteristic of $\mathrm{MgO}-\mathrm{SiO}_{2}$ derived sol-gel adsorbent

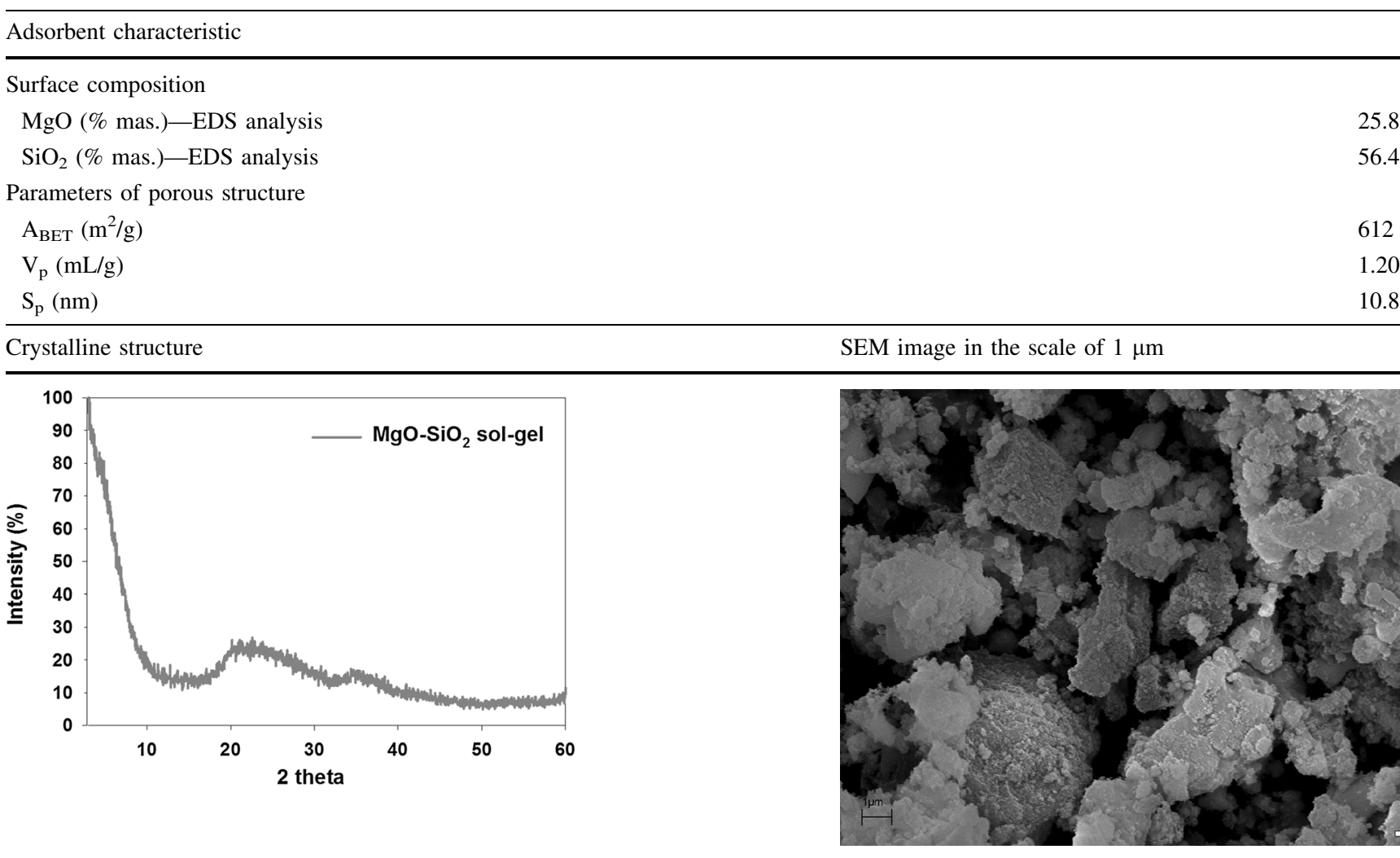

The standard deviation for the kinetics of the adsorption process was also determined using the formula (2):

$S D=\sqrt{\frac{\sum\left[\left(q_{e, \exp }-q_{e, c a l}\right) / q_{e, \exp }\right]^{2}}{n-1}}$

where $n$ is the number of data points, $q_{\exp }$ are the experimental data, and $q_{c a l}$ are the data obtained applying proper kinetic model. The higher the value of the correlation coefficient $\left(r^{2}\right)$, and the smaller the standard deviation $(S D)$, the better fit of experimental data to selected kinetic model.

To determine adsorption isotherms, tests were carried out at different concentrations (in the range of $25-500 \mathrm{mg} / \mathrm{L}$ ) of metal ions. The equilibrium concentration $\left(q_{e}\right)$ was calculated using the formula (3):

$q_{e}=\frac{\left(C_{0}-C_{e}\right) \cdot V}{m}$

where $q_{e}$ is the quantity of metal ions adsorbed at equilibrium $(\mathrm{mg} / \mathrm{g}), C_{0}$ is the initial concentration of metal ions $(\mathrm{mg} / \mathrm{L}), C_{e}$ is the equilibrium metal ions concentration $(\mathrm{mg} / \mathrm{L}), V$ is the volume of the solution (L), and $m$ is the mass of sol-gel derived adsorbent $(\mathrm{g})$.

To evaluate the goodness of fit of experimental data to the model, Chi square test is used (Ding et al. 2012). It is defined by Eq. (4): $\lambda^{2}=\sum_{i=1}^{m} \frac{\left(q_{e, \exp }-q_{e, c a l}\right)^{2}}{q_{e, \exp }}$

where $q_{e, c a l}$ is equilibrium capacity of metal ions adsorbed on sol-gel derived adsorbent and obtained from isotherm models, $q_{e, \text { exp }}$ is the equilibrium capacity obtained from the experimental data, and $m$ is the number of experimental data.

\section{Results and discussion}

\subsection{Adsorbent characterization}

Firstly, the physicochemical characteristics of the sol-gelderived $\mathrm{MgO}-\mathrm{SiO}_{2}$ adsorbent were investigated (Table 1). Analysis of the chemical composition of the adsorbent demonstrated the presence of two dominant components in its structure: $\mathrm{SiO}_{2}(63.3 \%)$ and $\mathrm{MgO}(36.5 \%)$. Due to the methodology of synthesis the amount of moisture was limited and was no more than $10 \%$. The results also showed that the resulting inorganic oxide adsorbent has a completely amorphous structure, which can be transformed into crystalline by the selection of an appropriate heat treatment technique (Ciesielczyk et al. 2014). On the one hand it is possible to obtain crystalline powder adsorbent, 
while on the other the moisture content can be completely reduced; this determines the surface activity, translating into a quantity of reactive silanol and magnesil groups ( $\equiv \mathrm{Si}-\mathrm{OH}$ and $-\mathrm{Mg}-\mathrm{OH}$ ). The nature of the adsorbent dispersion presented in the SEM photograph confirms the presence of particles of varying size and of irregular shape. The inorganic oxide adsorbent has a high surface area of $612 \mathrm{~m}^{2} / \mathrm{g}$, pore volume $\mathrm{V}_{\mathrm{p}}=1.20 \mathrm{~mL} / \mathrm{g}$ and pore diameter $\mathrm{S}_{\mathrm{p}}=10.8 \mathrm{~nm}$. The porous structure parameters confirm the mesoporous structure of the adsorbent.

\subsection{Sorption process}

The efficiency of adsorption of cadmium(II) and lead(II) ions on the inorganic oxide adsorbent obtained via the solgel route was determined on the basis of AAS analysis.

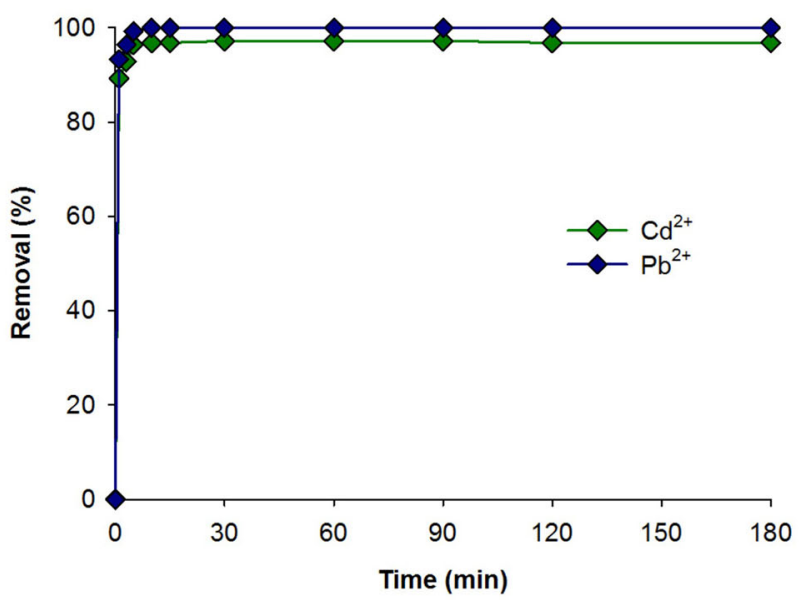

(a)
In the first stage, tests were carried out to determine the optimum time of cadmium or lead ion adsorption from model solutions in the three selected initial concentrations of 25,50 and $100 \mathrm{mg} / \mathrm{L}$ (Fig. 2).

Analysis of the relationships obtained (Fig. 2) showed that a high degree of removal of $\mathrm{Cd}$ (II) ions was already achieved after $1 \mathrm{~min}$ of adsorption. The effectiveness of adsorption reached $89.2,87.6$ and $85.3 \%$ for model cadmium ion solutions with initial concentrations of 25,50 and $100 \mathrm{mg} / \mathrm{L}$ respectively. This means that increasing the concentration of model $\mathrm{Cd}(\mathrm{II})$ ion solutions causes a slight decrease in the efficiency of removal of those ions. On the other hand, the longer the time of the adsorption process, the higher its efficiency, but the optimum time for adsorption of cadmium(II) ions seems to be $30 \mathrm{~min}$. The same situation was observed in the case of adsorption of

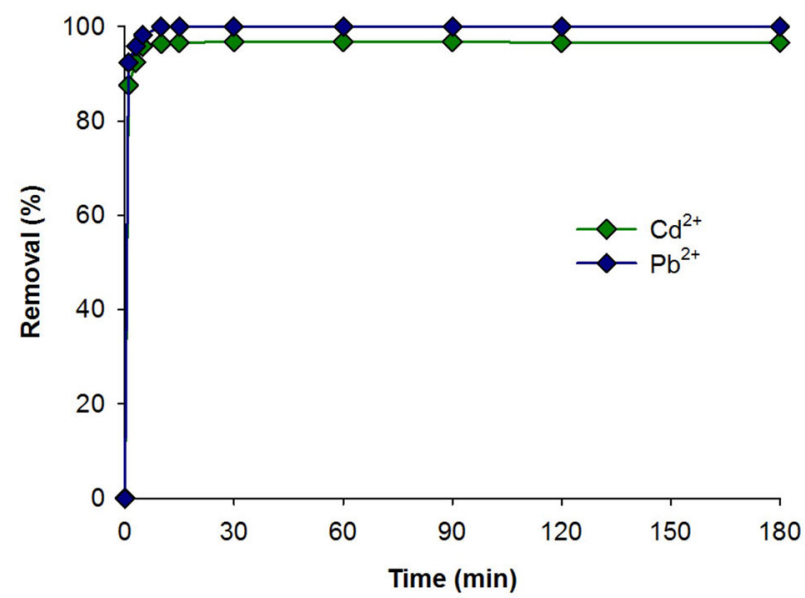

(b)

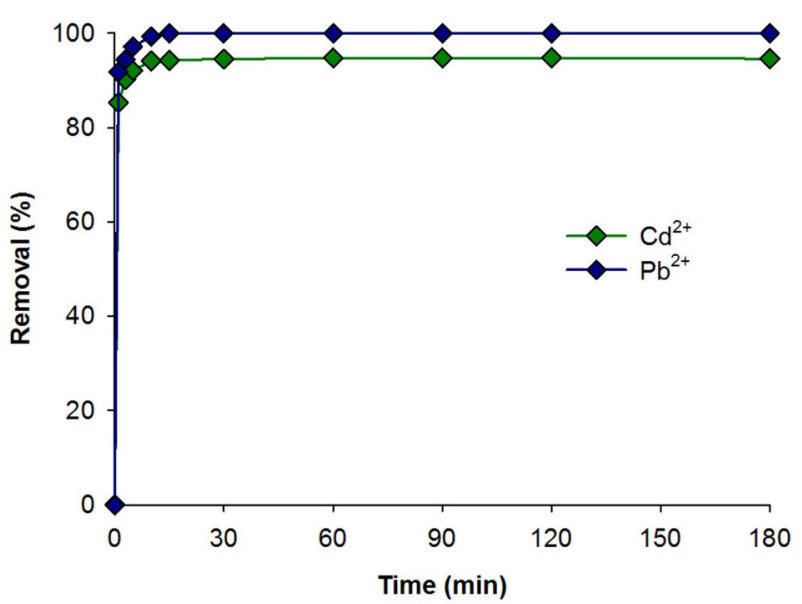

(c)

Fig. 2 Quantity of cadmium(II) and lead(II) ions adsorbed versus time using model solutions with concentrations of a $25 \mathrm{mg} / \mathrm{L}, \mathbf{b} 50 \mathrm{mg} / \mathrm{L}$ and c $100 \mathrm{mg} / \mathrm{L}$ (accuracy $\pm 0.5 \%$ ) (Color figure online) 
$\mathrm{Pb}$ (II) ions. This seems to be a very good result as compared with other published experimental data (Boroumand Jazi et al. 2014; Karthik and Meenakshi 2015a, b; Madrakian et al. 2014; Mahmoud and Mohamed 2014), which report that the equilibrium time for cadmium and lead removal using different adsorbents should be no shorter than $60 \mathrm{~min}$. Once again a relatively high efficiency of metal ion removal (above $90 \%$ ) was observed after 1 min of adsorption. The quantity of metal ions adsorbed decreases with an increase in its initial concentration in model solution, but only for adsorption process times in the range 1-5 min. The efficiency of adsorption reaches $100 \%$ after $10 \mathrm{~min}$ of the process with initial lead ion concentrations of 25 and $50 \mathrm{mg} / \mathrm{L}$, and after 15 min using metal ions in a concentration of $100 \mathrm{mg} / \mathrm{L}$. After that time no significant changes in the quantity of adsorbed metal ions were noted.

In both cases ( $\mathrm{Cd}$ (II) and $\mathrm{Pb}$ (II) ions) the equilibrium of adsorption was reached after $5 \mathrm{~min}$ using an adsorbate concentration of $25 \mathrm{mg} / \mathrm{L}$. For these model metal ion solutions, slightly better adsorption results were obtained in the case of lead(II) ions. Analogous results were recorded for higher concentrations of $\mathrm{Cd}(\mathrm{II})$ and $\mathrm{Pb}(\mathrm{II})$ ions (50 and $100 \mathrm{mg} / \mathrm{L}$ ), but the time after which the equilibrium of adsorption was reached was 10 and 15 min respectively, irrespective of the metal ion type. After that time, $\mathrm{Pb}$ (II) ions are practically all removed from the analyzed model solutions. It was shown that the time of the adsorption process is a crucial factor determining the efficiency of removal of metal ions from their model solutions using $\mathrm{MgO}-\mathrm{SiO}_{2}$ inorganic oxide adsorbent. The effectiveness of adsorption increases with time and in some cases decreases with increasing metal ion concentration, which also affects the time necessary to attain adsorption equilibrium. The maximum quantity of

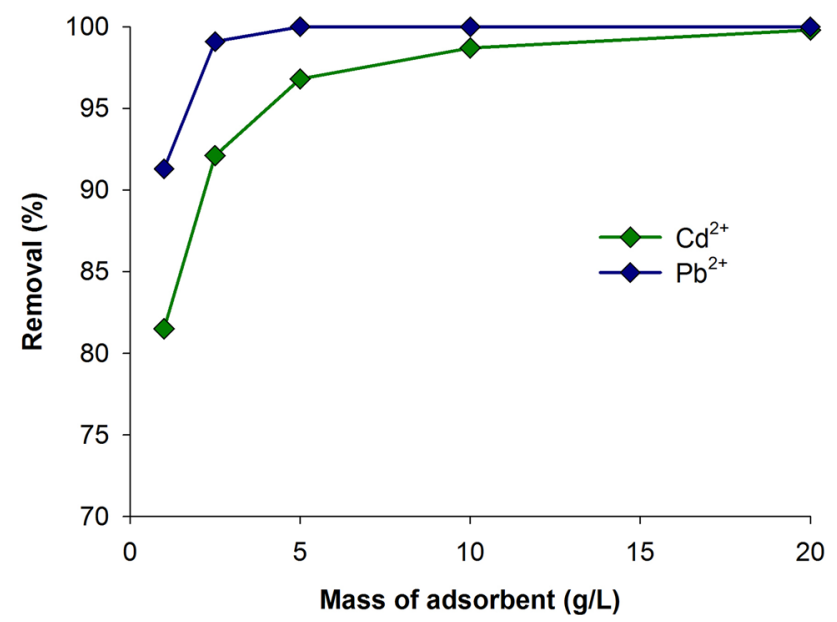

Fig. 3 Effect of adsorbent mass on the efficiency of $\mathrm{Cd}(\mathrm{II})$ and $\mathrm{Pb}(\mathrm{II})$ ion removal from model solutions with a concentration of $50 \mathrm{mg} / \mathrm{L}$ (adsorption time $60 \mathrm{~min}$, mass of the adsorbent $5 \mathrm{~g} / \mathrm{L}$, accuracy $\pm 0.5 \%$ ) (Color figure online)
cadmium(II) and lead(II) ions adsorbed in the optimal time was achieved for the highest metal ion concentration-18.96 and $20.00 \mathrm{mg} / \mathrm{g}$ respectively.

Figure 3 shows how the adsorbent mass $\left(\mathrm{MgO}-\mathrm{SiO}_{2}\right)$ influences the efficiency of adsorption of the analyzed metal ions. The results were obtained at constant adsorption time (60 min) and an initial metal ion concentration of $50 \mathrm{mg} / \mathrm{L}$. It was found, as expected, that by increasing the mass of oxide adsorbent the effectiveness of removal of $\mathrm{Cd}$ (II) and $\mathrm{Pb}$ (II) ions is also increased. This fact is confirmed by numerous literature reports (Mahmoud et al. 2015; Maliyekkal et al. 2010; Xiong et al. 2011) concerning different adsorbents used for the removal of cadmium and lead from aqueous solutions. The highest efficiencies of adsorption (100\%) were obtained utilizing 3 and $0.5 \mathrm{~g}$ of oxide adsorbent in the case of cadmium(II) and lead(II) ions respectively. The analyzed results confirmed that just $2 \mathrm{~g} / \mathrm{L}$ of oxide adsorbent is enough to obtain a satisfactory efficiency of metal ion removal from model solutions, and the use of $3 \mathrm{~g} / \mathrm{L}$ of adsorbent ensures $100 \%$ effectiveness of removal of both $\mathrm{Cd}(\mathrm{II})$ and $\mathrm{Pb}(\mathrm{II})$ ions. Slightly better adsorption results were obtained in the case of lead(II) ions, especially when using a smaller quantity of oxide adsorbent (for example, for $0.25 \mathrm{~g}$ of adsorbent the difference in adsorption was $7 \%$ in favor of lead). For this metal ion just $0.5 \mathrm{~g}$ of $\mathrm{MgO}-\mathrm{SiO}_{2}$ oxide adsorbent ensures its complete removal from model solution.

A key goal of the study was to evaluate the influence of the $\mathrm{pH}$ of the reaction system on the effectiveness of metal ion removal. As the $\mathrm{pH}$ was changed, different concentrations of metal ions and a constant mass of adsorbent $(5 \mathrm{~g} / \mathrm{L})$ were used, and the process was carried out for $60 \mathrm{~min}$. The experimental data collected (Fig. 4) clearly confirm that $\mathrm{Cd}(\mathrm{II})$ ions are adsorbed worse in acidic environments than neutral or alkaline. The difference between the effectiveness of adsorption measured at $\mathrm{pH} 1$ and 9 is $38.6 \%$. The highest degree of cadmium(II) ion removal (100\%) was obtained by adsorption at $\mathrm{pH} 9$ using a model solution with a concentration of $25 \mathrm{mg} / \mathrm{L}$. As the concentration of adsorbate solution increased, the quantity of metal ions adsorbed decreased, irrespective of the $\mathrm{pH}$ value. The same situation was observed in the case of removal of lead(II) ions. These ions were better adsorbed in alkaline medium $(\mathrm{pH} 7)$, where their total removal from model solutions at concentrations of 25 and $50 \mathrm{mg} / \mathrm{L}$ was noted. For pH 9 an adsorption efficiency of $100 \%$ was obtained irrespective of the solution concentration. Adsorption of lead(II) ions in an acidic medium gave much worse results, ranging from $64.3 \%$ using a model metal ion solution with a concentration of $100 \mathrm{mg} / \mathrm{L}$, up to $75.8 \%$ of ions removed from model solution with a concentration of $25 \mathrm{mg} / \mathrm{L}$. As in the case of Cd(II), increasing the concentration of lead(II) ions caused the effectiveness of the process to decrease. These results are in agreement 


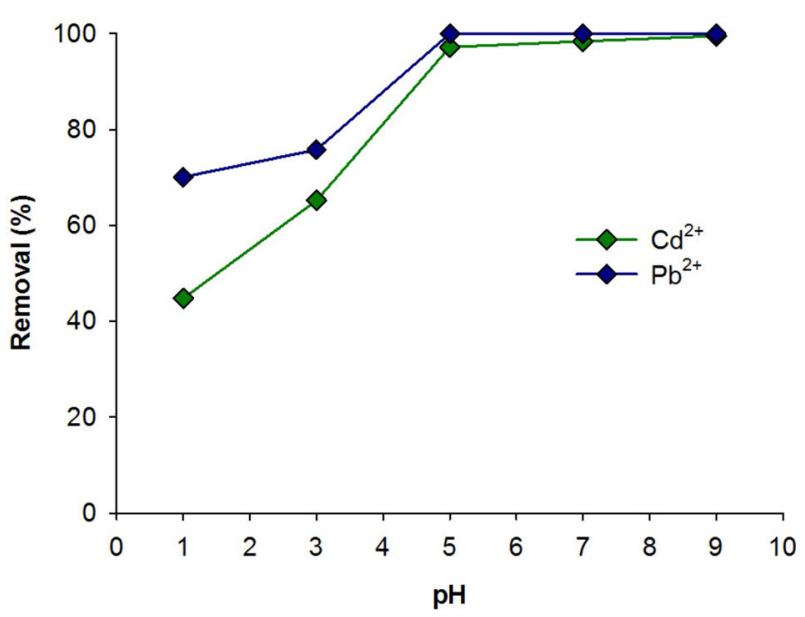

(a)

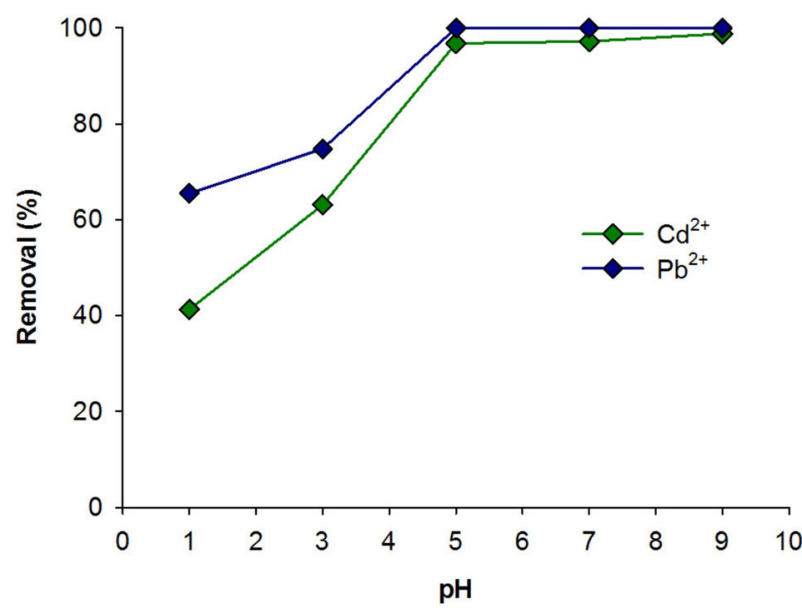

(b)

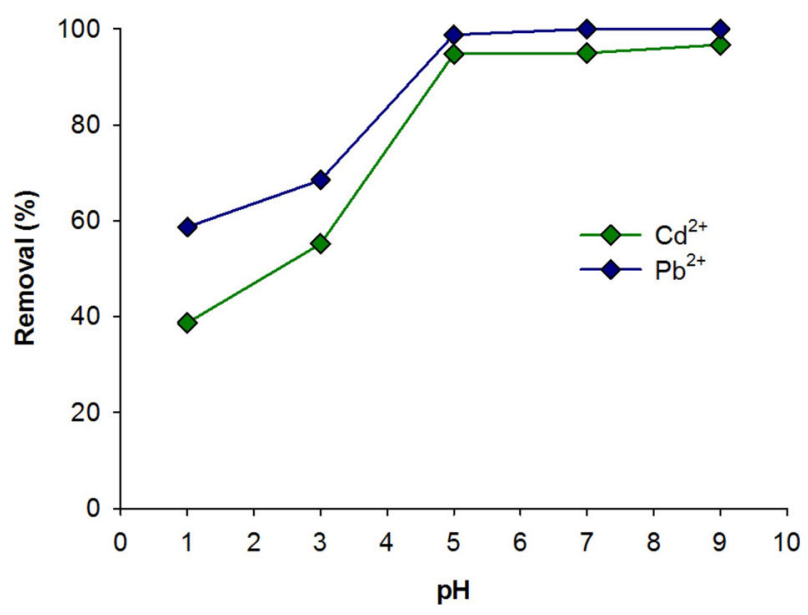

(c)

Fig. 4 Efficiency of adsorption versus $\mathrm{pH}$ for analyzed metal ions using model solutions with concentrations of a 25 , b 50 and $\mathbf{c} 100 \mathrm{mg} / \mathrm{L}$ (adsorption time $60 \mathrm{~min}$, accuracy $\pm 0.5 \%$ ) (Color figure online)

with experimental data reported by Mahmoud et al. (Mahmoud et al. 2000; Mahmoud and Mohamed 2014; Soliman et al. 2002), who studied cadmium and lead adsorption on nano-zirconium silicate. Those authors showed that metal ion adsorption at low $\mathrm{pH}$ values was less favorable due to the protonation of surface functional groups, which decreases with an increase in the $\mathrm{pH}$ value of the contact solution. Similar observations were reported by Boroumand Jazi et al., investigating the adsorption of the same metal ions on nanoscale organo-functionalized $\mathrm{SiO}_{2}-$ $\mathrm{Al}_{2} \mathrm{O}_{3}$ mixed oxide.

It was additionally shown that the powder material synthesized via the sol-gel route has negative surface charge over the whole $\mathrm{pH}$ range studied. This is confirmed by the electrokinetic curve showing the zeta potential as a function of $\mathrm{pH}$ (Fig. 5). This is a very important fact with regard to the adsorption of positively charged metal ions, as is the quantity of active hydroxyls present on the adsorbent surface as confirmed by the FTIR spectrum of the analyzed sample. The FTIR spectrum also shows signals characteristic for sol-gel-derived $\mathrm{MgO}-\mathrm{SiO}_{2}$ oxide adsorbent: $3650-3350 \mathrm{~cm}^{-1}$-stretching vibrations of hydroxyls; $1050 \mathrm{~cm}^{-1}$ and $890 \mathrm{~cm}^{-1}$ —stretching vibrations of Si-O bonds; $645 \mathrm{~cm}^{-1}$-deformation vibrations of $\mathrm{Si}-\mathrm{O}-\mathrm{Mg}$ bonds; $630 \mathrm{~cm}^{-1}$ —deformation vibrations of $\mathrm{O}-$ $\mathrm{Mg}-\mathrm{O}$ bonds; $540 \mathrm{~cm}^{-1}$ - stretching vibrations of $\mathrm{O}-\mathrm{Si}-\mathrm{O}$ (Chabrol et al. 2010; Ciesielczyk et al. 2014; Lan et al. 2012; Vishwas et al. 2011). According to the literature (Karthik and Meenakshi 2015a, b), low pH values are unfavorable for metal ion adsorption, since in that range they are present in solution in free form as $\mathrm{M}^{\mathrm{n}+}\left(\mathrm{Cd}^{2+}\right.$ and $\left.\mathrm{Pb}^{2+}\right)$, hence in this case there is an electrostatic repulsion between the cation and the more positively charged surface of the adsorbent. With increasing $\mathrm{pH}$, the adsorbent surface becomes more negatively charged-more $\mathrm{OH}^{-}$groups are generated (see Fig. 5) - and this fact allows metal ions, 


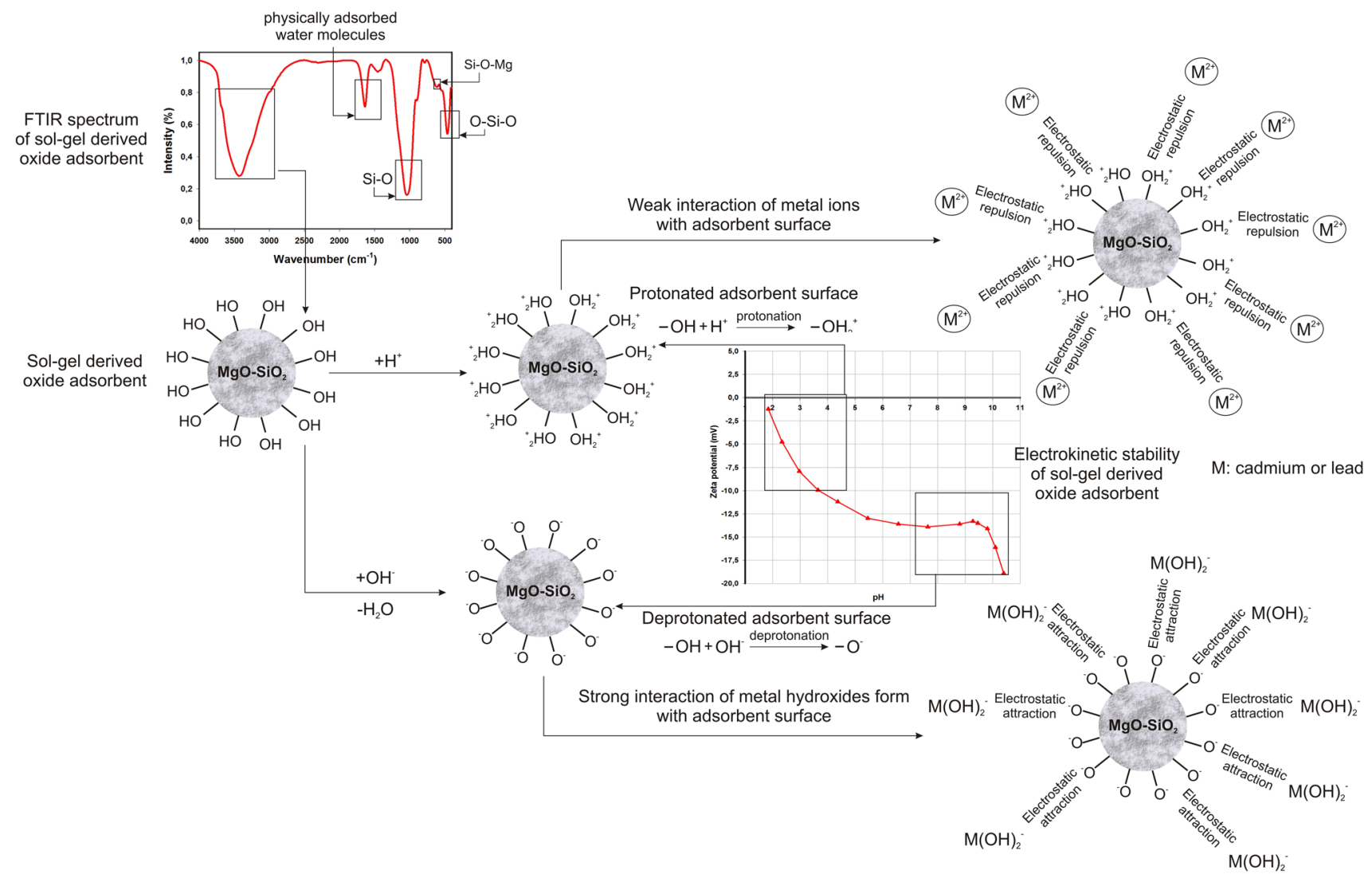

Fig. 5 Schematic presentation of $\mathrm{Cd}(\mathrm{II})$ and $\mathrm{Pb}(\mathrm{II})$ ions' interaction with oxide adsorbent surface at different $\mathrm{pH}$ values

Table 2 Efficiency of desorption of analyzed metal ions using water and chloric acid (desorption time $60 \mathrm{~min}$ )

\begin{tabular}{|c|c|c|c|c|}
\hline \multirow{3}{*}{$\begin{array}{l}\text { Initial metal ions } \\
\text { concentration }(\mathrm{mg} / \mathrm{L})\end{array}$} & \multicolumn{4}{|c|}{ Desorption efficiency $(\%)$} \\
\hline & \multicolumn{2}{|l|}{$\mathrm{H}_{2} \mathrm{O}$} & \multicolumn{2}{|c|}{$0.05 \mathrm{M} \mathrm{HCl}$} \\
\hline & $\mathrm{Cd}^{2+}$ & $\mathrm{Pb}^{2+}$ & $\mathrm{Cd}^{2+}$ & $\mathrm{Pb}^{2+}$ \\
\hline 25 & 2.0 & 2.2 & 84.5 & 89.9 \\
\hline 50 & 2.8 & 3.0 & 78.4 & 85.5 \\
\hline 100 & 5.9 & 6.0 & 70.2 & 79.6 \\
\hline
\end{tabular}

such as $\mathrm{Cd}(\mathrm{II})$ and $\mathrm{Pb}(\mathrm{II})$, to be adsorbed more effectively. In a strongly basic environment, the anions $\mathrm{M}(\mathrm{OH})_{\mathrm{m}}^{\mathrm{n}-}$ are formed, and these forms of metal ions, like cadmium or lead hydroxides, strongly interact with the surface of the inorganic oxide adsorbent, making adsorption easier. Figure 5 presents the schematic interactions between the analyzed metal ions and the $\mathrm{MgO}-\mathrm{SiO}_{2}$ oxide adsorbent surface in different environments.

\subsection{Desorption tests}

The degree of desorption of the analyzed metals from the surface of the oxide adsorbent using water and hydrochloric acid (Table 2) takes significantly different values. Lower desorption was observed in the case of water $(2.0-6.0 \%)$. Moreover, the higher the initial concentration of metal ions in solution, the greater the efficiency of their desorption. On the other hand, hydrochloric acid removed almost all of the cadmium and lead from the adsorbent surface, especially when adsorption was carried out using metal ion solutions with concentration $25 \mathrm{mg} / \mathrm{L}$ (desorption efficiency $84.5 \%$ for $\mathrm{Cd}(\mathrm{II})$ and $89.9 \%$ for $\mathrm{Pb}(\mathrm{II}))$. Unlike in the case of water, the efficiency of desorption realized using $\mathrm{HCl}$ decreased with increasing concentration of the model metal ion solution. In the case of both desorption agents, a slightly higher desorption efficiency was noted for lead(II). This fact proves the high stability of interactions between metal ions and the adsorbent surface, and indicates the possibility of adsorbent regeneration.

\subsection{Sorption kinetics}

Based on literature reports appropriate kinetic models were used for precise design of the adsorption process. To determine the rate constant of the adsorption process, the equations of Lagergren's pseudo-first-order kinetic model and Ho's pseudo-second-order kinetic model were applied. 
Table 3 Pseudo-first and pseudo-second-order kinetic parameters obtained by using the linear methods at different cadmium(II) and lead(II) ions concentration

\begin{tabular}{|c|c|c|c|c|c|c|}
\hline \multirow[t]{3}{*}{ Type of kinetic } & \multicolumn{2}{|c|}{ Parameter } & \multicolumn{4}{|c|}{ Concentration of metal ions (mg/L) } \\
\hline & \multirow[t]{2}{*}{ Symbol } & \multirow[t]{2}{*}{ Unit } & \multicolumn{2}{|l|}{25} & \multicolumn{2}{|l|}{100} \\
\hline & & & $\mathrm{Cd}^{2+}$ & $\mathrm{Pb}^{2+}$ & $\mathrm{Cd}^{2+}$ & $\mathrm{Pb}^{2+}$ \\
\hline \multirow{5}{*}{ Pseudo first order } & $q_{e, e x p}$ & $\mathrm{mg} \mathrm{g}^{-1}$ & 4.86 & 5.00 & 18.96 & 20.00 \\
\hline & $k_{1}$ & $1 / \min$ & 0.341 & 0.535 & 0.113 & 0.280 \\
\hline & $r^{2}$ & - & 0.875 & 0.948 & 0.783 & 0.983 \\
\hline & $q_{e, c a l}$ & $\mathrm{mg} / \mathrm{g}$ & 0.46 & 0.67 & 1.01 & 2.35 \\
\hline & $S D$ & $\%$ & 43.22 & 35.68 & 53.98 & 19.95 \\
\hline \multicolumn{7}{|c|}{ Pseudo second order } \\
\hline \multirow[t]{5}{*}{ Type 1} & $q_{e, c a l}$ & $\mathrm{mg} \mathrm{g}^{-1}$ & 4.84 & 5.00 & 18.95 & 20.01 \\
\hline & $k_{2}$ & $\mathrm{~g} \mathrm{mg}^{-1} \min$ & 9.736 & 5.067 & 2.738 & 11.888 \\
\hline & $h$ & $\mathrm{mg} \mathrm{g}^{-1} \min$ & 22.40 & 26.76 & 65.08 & 76.90 \\
\hline & $r^{2}$ & - & 0.999 & 0.999 & 0.999 & 0.999 \\
\hline & $S D$ & $\%$ & 6.01 & 7.08 & 6.25 & 7.89 \\
\hline \multirow[t]{5}{*}{ Type 2} & $q_{e, c a l}$ & $\mathrm{mg} \mathrm{g}^{-1}$ & 4.86 & 5.01 & 18.95 & 19.97 \\
\hline & $k_{2}$ & $\mathrm{~g} \mathrm{mg}^{-1} \min$ & 2.199 & 2.572 & 0.458 & 0.516 \\
\hline & $h$ & $\mathrm{mg} \mathrm{g}^{-1} \min$ & 52.02 & 64.54 & 164.48 & 205.72 \\
\hline & $r^{2}$ & - & 0.939 & 0.950 & 0.979 & 0.895 \\
\hline & $S D$ & $\%$ & 10.54 & 13.56 & 13.12 & 20.52 \\
\hline \multirow[t]{5}{*}{ Type 3} & $q_{e, c a l}$ & $\mathrm{mg} \mathrm{g}^{-1}$ & 4.87 & 5.01 & 18.96 & 20.01 \\
\hline & $k_{2}$ & $\mathrm{~g} \mathrm{mg}^{-1} \min$ & 2.060 & 2.440 & 0.448 & 0.460 \\
\hline & $h$ & $\mathrm{mg} \mathrm{g}^{-1} \min$ & 48.84 & 61.33 & 161.05 & 184.16 \\
\hline & $r^{2}$ & - & 0.939 & 0.950 & 0.979 & 0.895 \\
\hline & $S D$ & $\%$ & 12.98 & 17.52 & 12.99 & 19.59 \\
\hline \multirow[t]{5}{*}{ Type 4} & $q_{e, c a l}$ & $\mathrm{mg} \mathrm{g}^{-1}$ & 4.87 & 4.72 & 18.97 & 18.70 \\
\hline & $k_{2}$ & $\mathrm{~g} \mathrm{mg}^{-1} \min$ & 2.046 & 2.428 & 0.445 & 0.454 \\
\hline & $h$ & $\mathrm{mg} \mathrm{g}^{-1} \min$ & 48.51 & 61.02 & 159.85 & 181.99 \\
\hline & $r^{2}$ & - & 0.933 & 0.946 & 0.977 & 0.890 \\
\hline & $S D$ & $\%$ & 11.87 & 16.92 & 17.52 & 21.32 \\
\hline
\end{tabular}

\subsubsection{Pseudo-first-order kinetic model}

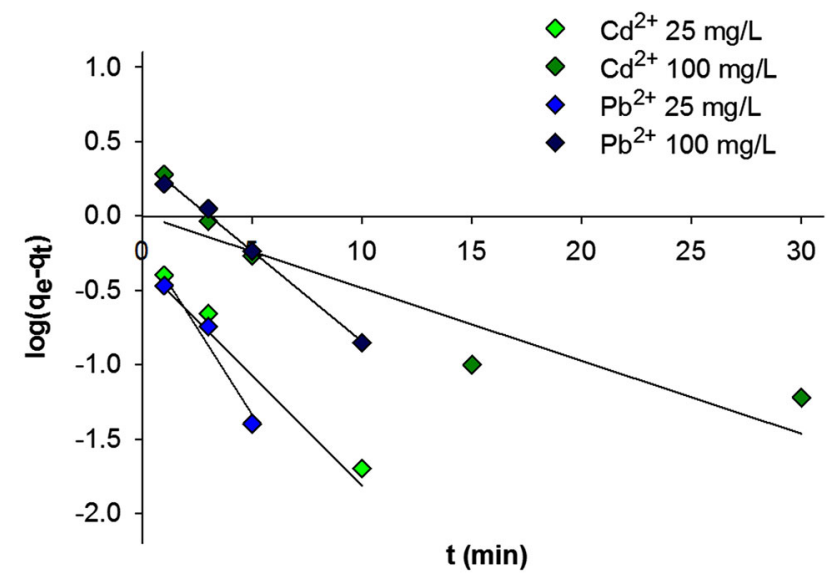

Fig. 6 Pseudo-first-order kinetic fit for adsorption of cadmium(II) and lead(II) ions on synthesized oxide adsorbent (Color figure online)
A linear model of pseudo-first-order adsorption kinetics is defined by Lagergren's Eq. (5):

$\log \left(q_{e}-q_{t}\right)=\log q_{e}-\frac{k_{1}}{2.303} \cdot t$

where $q_{e}$ and $q_{t}(\mathrm{mg} / \mathrm{g})$ are the quantities of metal ions adsorbed at equilibrium and at time $t(\mathrm{~min})$ respectively, and $k_{1}(1 / \mathrm{min})$ is the rate constant for the pseudo-first-order model. The equilibrium adsorption capacity $\left(q_{e}\right)$ and adsorption rate constant $\left(k_{1}\right)$ (Table 3 ) can be computed experimentally by plotting $\log \left(q_{e}-q_{t}\right)$ against $t$. A graph of $\log \left(q_{e}-q_{t}\right)$ versus $t$ for the pseudo-first-order case is shown in Fig. 6. Table 3 gives the values of the adsorption rate constant $\left(k_{1}\right)$ for particular concentrations of selected metal ions, calculated from the gradients in Fig. 6. It was observed that 


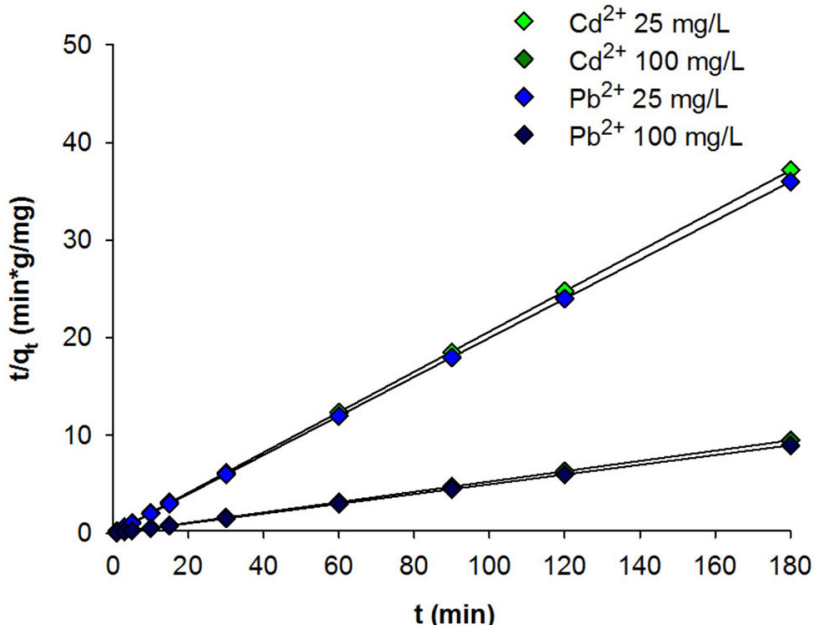

(a)

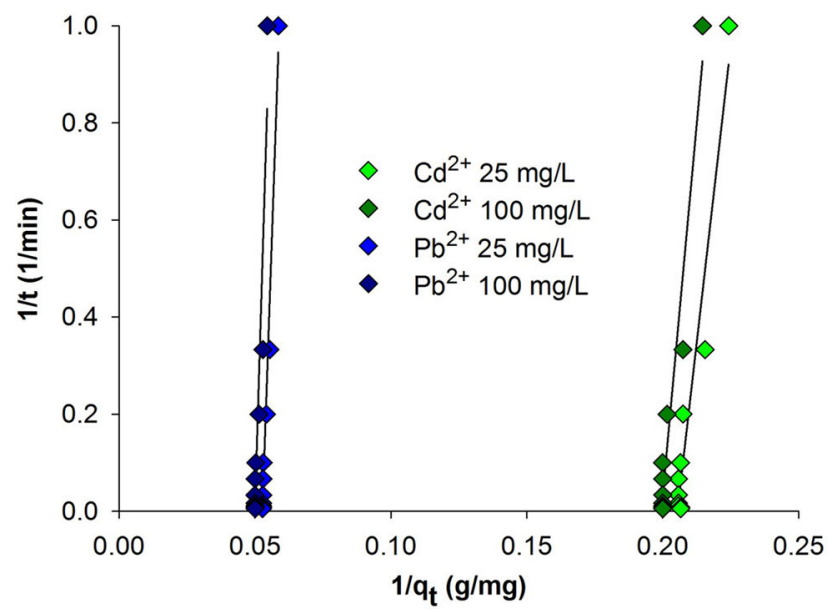

(c)

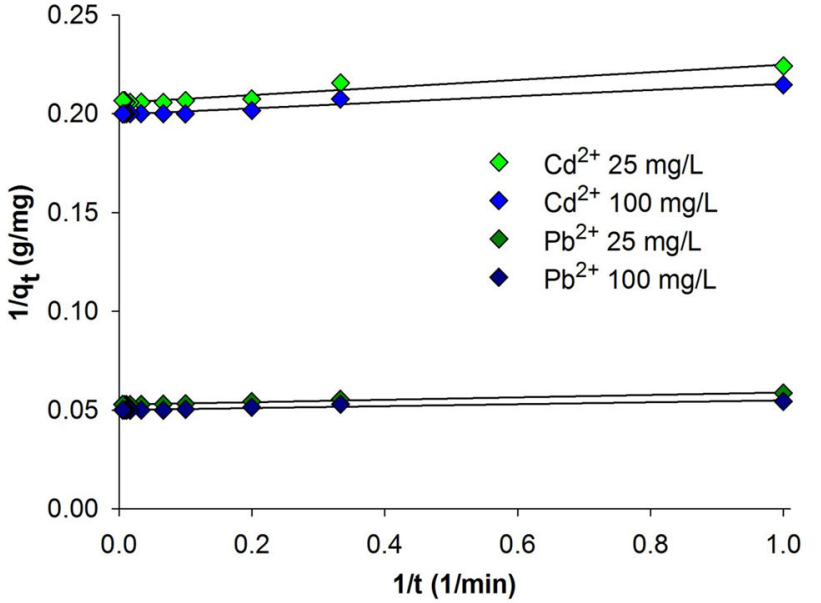

(b)

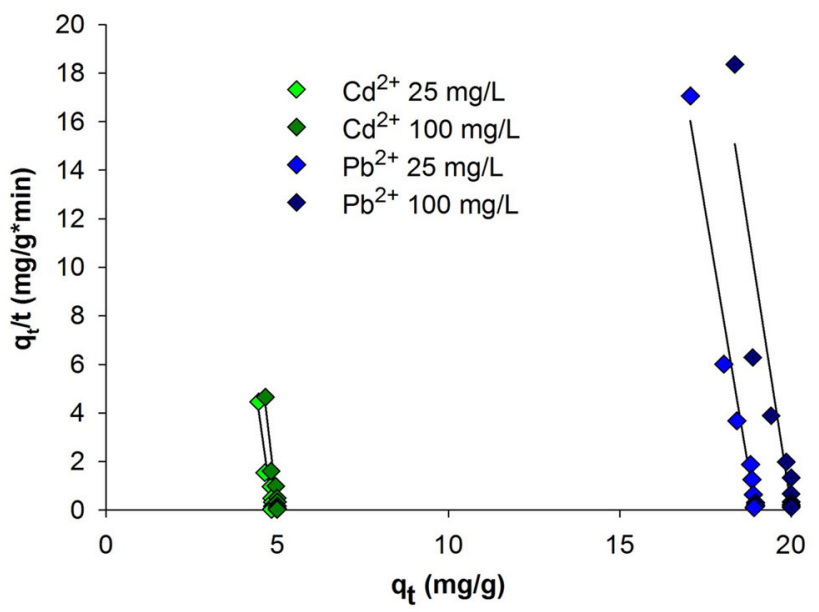

(d)

Fig. 7 Pseudo-second-order kinetic fit for adsorption of cadmium(II) and lead(II) ions on oxide adsorbent: a type 1, b type 2, c type 3 and d type 4 (Color figure online)

the rate constants of the adsorption processes $\left(k_{1}\right)$ for the cadmium(II) ion concentrations studied $(25$ and $100 \mathrm{mg} / \mathrm{L})$ were 0.10 and 0.11 respectively, while for lead(II) ions the values were 0.54 and 0.28 . The correlation coefficient is found to increase with a rise in the concentration of the metal ions. It was confirmed that the pseudo-first-order kinetic model well describes the adsorption of lead ions on $\mathrm{MgO}$ $\mathrm{SiO}_{2}$ adsorbent. However, the results for adsorption capacity $\left(q_{e, c a l}\right)$ obtained based on the pseudo-first-order kinetic model calculations deviated significantly from the values of the experimental capacities $\left(q_{e, \text { exp }}\right)$. Much better results were obtained using the pseudo-second-order kinetic model, which is a confirmation of previously published results (Guo et al. 2014; Boroumand Jazi et al. 2014). Adsorption of cadmium and lead ions on both natural (chitosan, modified lingo-cellulosic material) and synthetic (grafted silica and silicates) adsorbents is described extremely well by a pseudo-second-order kinetic model.

\subsubsection{Pseudo-second-order kinetic model}

A linear model of pseudo-second-order adsorption kinetics is defined by Eq. (6):

$\frac{t}{q_{t}}=\frac{1}{k_{2} \cdot q_{e}^{2}}+\frac{1}{q_{e}} \cdot t$

where $k_{2}$ ( $\mathrm{g} / \mathrm{mg}$ min) is the rate constant for the pseudosecond-order rate equation, and $q_{e}$ and $q_{t}$ are the quantities (mg/g) of cadmium(II) ions adsorbed at equilibrium and at time $t(\mathrm{~min})$ respectively.

The initial adsorption rate $h(\mathrm{~g} / \mathrm{mg} \min )$ is defined as follows: 


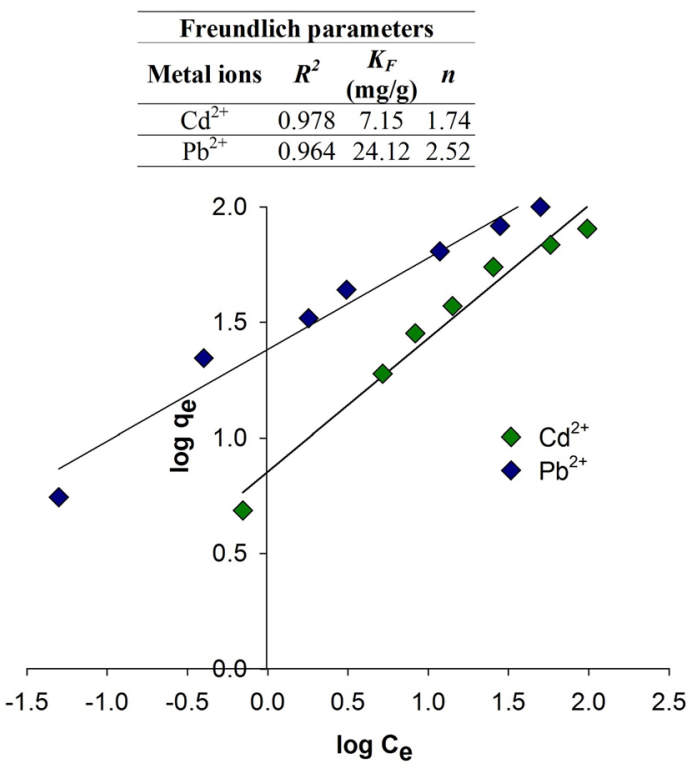

(a)
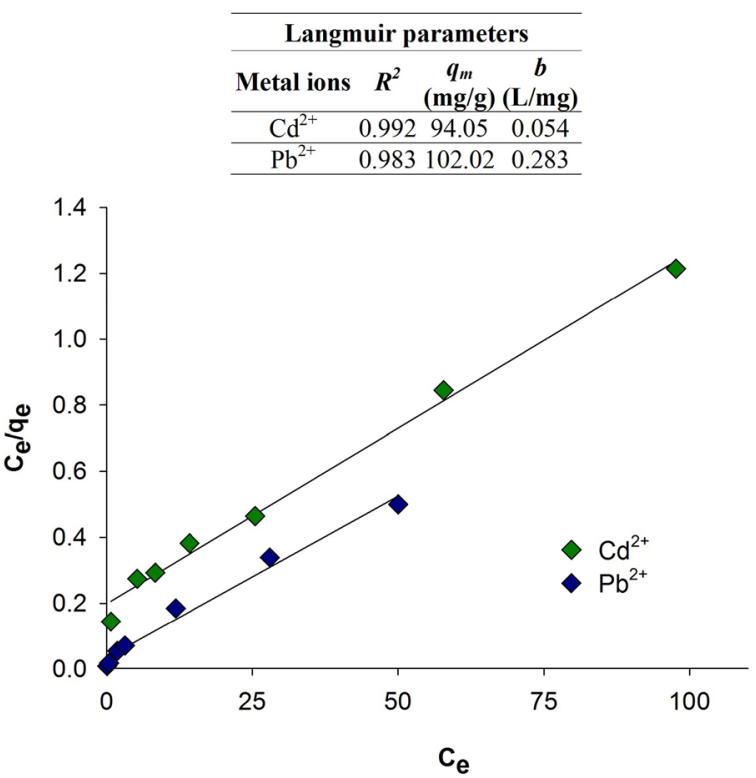

(b)

Fig. 8 Freundlich and Langmuir isotherm fit for adsorption of metal ions onto sol-gel derived oxide adsorbent (Color figure online)

Table 4 Adsorption capacities of different adsorbents towards removal of $\mathrm{Cd}(\mathrm{II})$ and $\mathrm{Pb}(\mathrm{II})$ ions

\begin{tabular}{|c|c|c|c|}
\hline Metal ion & Adsorbent type & $q_{m}(\mathrm{mg} / \mathrm{g})$ & Reference \\
\hline $\mathrm{Pb}^{2+}$ & Sol-gel dervied $\mathrm{MgO}-\mathrm{SiO}_{2}$ & 102.02 & This study \\
\hline $\mathrm{Cd}^{2+}$ & Sol-gel dervied $\mathrm{MgO}-\mathrm{SiO}_{2}$ & 94.05 & This study \\
\hline $\mathrm{Pb}^{2+}$ & Ion-imprinted silica sorbent & 65.80 & Fan et al. (2014a) \\
\hline $\mathrm{Cd}^{2+}$ & IIP-AAAPTS/SiO ${ }_{2}$ & 60.60 & Fan et al. (2012) \\
\hline $\mathrm{Pb}^{2+}$ & Tetrasulfidefunctionalized silica & 52.90 & Fan et al. (2012) \\
\hline $\mathrm{Cd}^{2+}$ & IIP-TCPTS/SiO ${ }_{2}$ & 49.30 & Li et al. (2011) \\
\hline $\mathrm{Cd}^{2+}$ & $\mathrm{MgO}-\mathrm{SiO}_{2}$ (water precipitation) & 35.86 & Ciesielczyk et al. (2015) \\
\hline $\mathrm{Cd}^{2+}$ & Imprinted hybrid sorbents & 29.10 & Fan et al. (2014b) \\
\hline $\mathrm{Pb}^{2+}$ & Polyaniline-grafted-chitosan & 13.23 & Karthik and Meenakshi $(2015 a, b)$ \\
\hline $\mathrm{Cd}^{2+}$ & Polyaniline-grafted-chitosan & 12.87 & Karthik and Meenakshi $(2015 a, b)$ \\
\hline
\end{tabular}

$h=k_{2} \cdot q_{e}^{2}$

The values $k_{2}$ and $q_{e}$ may be determined from the gradient and intercept respectively of the plot of $t / q t$ versus $t$. This relationship can be classed as a type 1 pseudosecond-order kinetic model. There are other subtypes of pseudo-second-order model which can also be used to compute the values $k_{2}$ and $q_{e}$.

By plotting the above curves (Fig. 7) it is possible to estimate the model value of the concentration of analyzed metal ions on the adsorbent surface, and the rate constants $\left(k_{2}\right)$ for saturation of the sorption capacity of the MgO$\mathrm{SiO}_{2}$ oxide system (Table 3 ).

The kinetics of the adsorption of cadmium(II) and lea$\mathrm{d}$ (II) ions from model solutions with concentrations of 25 and $100 \mathrm{mg} / \mathrm{L}$ on an inorganic oxide adsorbent are very well described by the first type of pseudo-second-order kinetic model. This is confirmed by the high value of the correlation coefficient $\left(r^{2}\right)$, which reached 1.000 (Table 3) for initial cadmium(II) and lead(II) ion concentrations of $100 \mathrm{mg} / \mathrm{L}$. A decrease in the rate constant of the adsorption process $\left(k_{2}\right)$ was observed as the initial concentration of cadmium(II) ions increased, although it increased as the initial concentration of lead(II) ions increased. The adsorption capacity $\left(q_{e}, r_{c a l}\right)$ obtained from the type 1 pseudo-second-order kinetic equation corresponded well with the experimental capacities $\left(q_{e, \text { exp }}\right)$. The parameters obtained indicate the possibility of using a type 1 pseudosecond-order model for predicting the kinetics of cadmium and lead ion adsorption on $\mathrm{MgO}-\mathrm{SiO}_{2}$ oxide adsorbent.

For subsequent types (2-3) of pseudo-second-order kinetic models (Fig. 7; Table 3) the adsorption capacities 
$\left(q_{e, c a l}\right)$ calculated based on the selected type of kinetic model correspond closely to the experimental capacities $\left(q_{e, \text { exp }}\right)$ for both $\mathrm{Cd}(\mathrm{II})$ and $\mathrm{Pb}$ (II) ions. With increasing concentration of metal ions, a decrease in the adsorption rate constant $\left(k_{2}\right)$ and an increase in the value $q_{e, \text { exp }}$ were observed. It should be noted that the correlation coefficient lies in the range $0.895-0.979$, which confirms a significant variance fit of the experimental data to the applied type 2 and 3 pseudo-second-order kinetic models.

For a type 4 pseudo-second-order kinetic model (Fig. 7d; Table 3) unfavorable results were obtained. The correlation coefficient was in the range $0.933-0.977$ in the case of cadmium(II) ions and $0.890-0.946$ for lead(II) ions. This confirms the mediocre fit of the experimental results to the applied type 4 kinetic model.

The evaluation of adsorption isotherms was a key goal of the research. Two most popular models of isotherms, Langmuir (1918) and Freundlich (1906), were used for this purpose. The results make it possible to determine the sorption capacities of the materials used and to identify the mechanism of adsorption.

Linear form of Langmuir equation is presented below:

$\frac{C_{e}}{q_{e}}=\frac{1}{b \cdot q_{m}}+\frac{C_{e}}{q_{m}}$

where $C_{e}$ is the equilibrium concentration of metal ions $(\mathrm{mg} / \mathrm{L}), q_{e}$ is the quantity of metal ions adsorbed per unit mass of adsorbent $(\mathrm{mg} / \mathrm{g})$, and $q_{m}(\mathrm{mg} / \mathrm{g})$ and $b(\mathrm{~L} / \mathrm{mg}) \cdot(\mathrm{L} / \mathrm{g})$ are the Langmuir constants representing the maximum adsorption capacity. Mentioned parameters were estimated from graphical interpretation of $C_{e} / q_{e}$ versus $C_{e}$ dependence (Fig. 8a).

The linear form of the Freundlich model is given by:

$\log q_{e}=\log K_{F}+\log C_{e}^{\frac{1}{n}}$

where $K_{F}(\mathrm{mg} / \mathrm{g})$ and $n$ are the Freundlich constants. Values of $K_{f}$ and $n$ are calculated based on $\log \left(q_{e}\right)$ versus $\log \left(C_{e}\right)$ dependence (Fig. 8b).

Figure 8 presents parameters of Freundlich and Langmuir models. Experimental data concerning adsorption of cadmium(II) and lead(II) ions onto sol-gel derived $\mathrm{MgO}-$ $\mathrm{SiO}_{2}$ adsorbent are better described with Langmuir isotherm model. Confirmation of this fact is relative high value of coefficient factor $\left(r^{2}=0.992\right.$ and 0.983$)$ and smaller $\lambda^{2}$ values (1.19 and 1.98). In this case, adsorption may occur inside the pores as confirmed by experimental data fit to the specific model.

Maximal sorption capacity of sol-gel derived adsorbent towards cadmium(II) and lead(II) ions equals 94.05 and $102.02 \mathrm{mg} / \mathrm{g}$ respectively. The comparison of maximum monolayer adsorption capacity of $\mathrm{Cd}^{2+}$ and $\mathrm{Pb}^{2+}$ ions onto different, synthetic adsorbents is presented in Table 4.
As compared to sorption capacities of other materials, synthesis of $\mathrm{MgO}-\mathrm{SiO}_{2}$ adsorbent via sol-gel route and its application in adsorption of analysed metal ions was reasoned. Material with high affinity towards removal of cadmium(II) and lead(II) ions form water solutions was obtained.

Application of Freundlich isotherm model allowed to obtain coefficient factor $\left(r^{2}\right) 0.978$ and 0.964 for adsorption of $\mathrm{Cd}^{2+}$ and $\mathrm{Pb}^{2+}$ ions respectively. It is definitely lower than this obtained applying Langmuir isotherm model. The $\lambda^{2}$ value of 2.98 and 11.87 is also higher. Additionally, the $n$ values were higher than 1 , which prove a proper course of adsorption process and its physical nature.

\section{Conclusions}

Comprehensive analysis of the experimental data proved the high efficiency of sol-gel-derived $\mathrm{MgO}-\mathrm{SiO}_{2}$ oxide adsorbent in the removal of both cadmium(II) and lead(II) ions from model aqueous solutions. This fact is indirectly related to the proposed method of its synthesis, which makes it possible to control the porous structure parameters of such oxide adsorbents $\left(\mathrm{A}_{\mathrm{BET}}=612 \mathrm{~m}^{2} / \mathrm{g}, \mathrm{V}_{\mathrm{p}}=1.20\right.$ $\mathrm{mL} / \mathrm{g}, \mathrm{Sp}=10.8 \mathrm{~nm})$. Additionally, it was confirmed that the adsorption process was highly dependent on the contact time of the reactants, the metal ion concentration, the adsorbent dosage, and particularly the $\mathrm{pH}$.

Efficiency of adsorption of $\mathrm{Cd}(\mathrm{II})$ and $\mathrm{Pb}$ (II) ions on the inorganic oxide adsorbent increased with increasing time. For selected concentrations of metal ion solution, adsorption equilibrium was established after $10 \mathrm{~min}$ in the case of lead(II) and after $15 \mathrm{~min}$ for cadmium(II) ions, and $60 \mathrm{~min}$ was the time after which the maximum efficiency of adsorption was obtained. On the other hand, increasing the concentration of both model metal ion solutions caused a significant decrease in the effectiveness of ion removal. Moreover, as expected, it was found that increasing the mass of oxide adsorbent caused an increase in the effectiveness of removal of $\mathrm{Cd}(\mathrm{II})$ and $\mathrm{Pb}(\mathrm{II})$ ions. This is related to the increasing quantity of active sites present on the oxide adsorbent surface that can easily react with metal ions. Lead(II) ions exhibit much better affinity to the adsorbent surface, irrespective of the process conditions.

The $\mathrm{pH}$ of the model metal ion solution was found to be the most important factor influencing the effectiveness of the adsorption process. The lowest efficiencies, for both cadmium(II) and lead(II) ions, were obtained in an acidic environment, and with increasing alkalinity of the reaction system the adsorption affinity of $\mathrm{MgO}-\mathrm{SiO}_{2}$ for metal ions increased. This was confirmed by an evaluation of electrokinetic stability, which proved the significant role of $\mathrm{pH}$ 
in determining the surface properties of such oxide adsorbents.

The possibility of adsorbent regeneration was confirmed by desorption tests, particularly when hydrochloric acid solution was used.

Additional kinetic studies confirmed that the results for adsorption capacity $\left(q_{e, c a l}\right)$ obtained based on the pseudofirst-order kinetic model calculations deviated significantly from the values of the experimental capacities $\left(q_{e, \exp }\right)$. Much better results were obtained using the pseudo-second-order kinetic model. Moreover, material exhibit high affinity towards removal of cadmium(II) and lead(II) ions form water solutions as confirmed by relative high values of sorption capacities, 94.05 and $102.02 \mathrm{mg} / \mathrm{g}$ respectively.

The experimental data collected and relationships established, as well as the analysis of kinetic models of the adsorption process, indicate the successful removal of both metal ions from model solutions utilizing $\mathrm{MgO}-\mathrm{SiO}_{2}$ oxide adsorbent.

Acknowledgments The study was financed within the National Science Centre (Poland) funds according to Decision No. DEC-2011/ 03/D/ST5/05802.

Open Access This article is distributed under the terms of the Creative Commons Attribution 4.0 International License (http://crea tivecommons.org/licenses/by/4.0/), which permits unrestricted use, distribution, and reproduction in any medium, provided you give appropriate credit to the original author(s) and the source, provide a link to the Creative Commons license, and indicate if changes were made. The Creative Commons Public Domain Dedication waiver (http://creativecommons.org/publicdomain/zero/1.0/) applies to the data made available in this article, unless otherwise stated.

\section{References}

Barakat, M.A., Kumar, R.: Synthesis and characterization of porous magnetic silica composite for the removal of heavy metals from aqueous solution. J. Ind. Eng. Chem. 23, 93-99 (2015)

Borhade, A.V., Kshirsagar, T.A., Dholi, A.G., Agashe, J.A.: Removal of heavy metals $\mathrm{Cd}^{2+}, \mathrm{Pb}^{2+}$, and $\mathrm{Ni}^{2+}$ from aqueous solutions using synthesized azide cancrinite, $\mathrm{Na}_{8}\left[\mathrm{AlSiO}_{4}\right]_{6}\left(\mathrm{~N}_{3}\right)_{2.4}\left(\mathrm{H}_{2} \mathrm{O}\right)_{4.6}$. J. Chem. Eng. Data 60, 586-593 (2015)

Boroumand Jazi, M., Arshadi, M., Amiri, M.J., Gil, A.: Kinetic and thermodynamic investigations of $\mathrm{Pb}$ (II) and $\mathrm{Cd}$ (II) adsorption on nanoscale organo-functionalized $\mathrm{SiO}_{2} \mathrm{Al}_{2} \mathrm{O}_{3}$. J. Colloid Interface Sci. 422, 16-24 (2014)

Chabrol, K., Gressier, M., Pebere, N., Menu, M.J., Martin, F., Bonino, J.P., Marichal, C., Brendle, J.: Functionalization of synthetic talc-like phyllosilicates by alkoxyorganosilane grafting. J. Mater. Chem. 20, 9695-9706 (2010)

Ciesielczyk, F., Przybysz, M., Zdarta, J., Piasecki, A., Paukszta, D., Jesionowski, T.: The sol-gel approach as a method of synthesis of $\mathrm{xMgO}-\mathrm{ySiO}$, powder with defined physicochemical properties including crystalline structure. J. Sol-Gel. Sci. Technol. 71, 501-513 (2014)

Ciesielczyk, F., Bartczak, P., Jesionowski, T.: Removal of nickel(II) and cadmium(II) ions from aqueous solutions using an oxide adsorbent of $\mathrm{MgO} \cdot \mathrm{SiO}_{2}$ type. Desalin. Water Treat. 55, 1271-1284 (2015)
Cutillas-Barreiro, L., Ansias-Manso, L., Fernández-Calviño, D., Arias-Estévez, M., Nóvoa-Muñoz, J.C., Fernández-Sanjurjo, M.J., Álvarez-Rodríguez, E., Núñez-Delgado, A.: Pine bark as bio-adsorbent for $\mathrm{Cd}, \mathrm{Cu}, \mathrm{Ni}, \mathrm{Pb}$ and $\mathrm{Zn}$ : batch-type and stirred flow chamber experiments. J. Environ. Manage. 144, 258-264 (2014)

Ding, L., Lu, X., Deng, H., Zhang, X.: Adsorptive removal of 2,4dichlorophenoxyacetic acid (2,4-D) from aqueous solutions using MIEX resin. Ind. Eng. Chem. Res. 51, 11226-11235 (2012)

Dubey, S.P., Gopal, K., Bersillon, J.L.: Utility of adsorbents in the purification of drinking water: a review of characterization, efficiency and safety evaluation of various adsorbents. J. Environ. Biol. 30, 327-332 (2009)

Ezzeddine, Z., Batonneau-Gener, I., Pouilloux, Y., Hamad, H., Saad, Z., Kazpard, V.: Divalent heavy metals adsorption onto different types of EDTA-modified mesoporous materials: effectiveness and complexation rate. Micropor. Mesopor. Mater. 212, 125-136 (2015)

Fan, H.-T., Sun, X.-T., Li, W.-X.: Sol-gel derived ion-imprinted silica-supported organic-inorganic hybrid sorbent for selective removal of lead(II) from aqueous solution. J. Sol-Gel. Sci. Technol. 72, 144-155 (2014a)

Fan, H.-T., Liu, J.-X., Yao, H., Zhang, Z.-G., Yan, F., Li, W.-X.: Ionic imprinted silica-Supported hybrid sorbent with an anchored chelating schiff base for selective removal of cadmium(II) ions from aqueous media. Ind. Eng. Chem. Res. 53, 369-378 (2014b)

Fan, H.-T., Sun, X.-T., Zhang, Z.-G., Li, W.-X.: Selective removal of lead(II) from aqueous solution by an ion-imprinted silica sorbent functionalized with chelating N-donor atoms. J. Chem. Eng. Data 59, 2106-2114 (2014c)

Fan, H.-T., Li, J., Li, Z-Ch., Sun, T.: An ion-imprinted aminofunctionalized silica gel sorbent prepared by hydrothermal assisted surface imprinting technique for selective removal of cadmium(II) from aqueous solution. Appl. Surf. Sci. 258, 3815-3822 (2012)

Freundlich, H.M.F.: Over the adsorption in solution. J. Phys. Chem. 57, 385-470 (1906)

Guo, X., Du, B., Wei, Q., Yang, J., Hu, L., Yan, L., Xu, W.: Synthesis of amino functionalized magnetic graphenes composite material and its application to remove $\mathrm{Cr}(\mathrm{VI}), \mathrm{Pb}$ (II), $\mathrm{Hg}$ (II), $\mathrm{Cd}(\mathrm{II})$ and $\mathrm{Ni}(\mathrm{II})$ from contaminated water. J. Hazard. Mater. 278, 211-220 (2014)

Gupta, S., Bhattacharyya, K.G.: Adsorption of heavy metals on kaolinite and montmorillonite: a review. Phys. Chem. Chem. Phys. 14, 6698-6723 (2012)

Gupta, S., Bhattacharyya, K.G.: Adsorption of metal ions by clays and inorganic solids. RSC Adv. 4, 28537-28586 (2014)

Hassan, A.F., Abdelghny, A.M., Elhadidy, H., Youssef, A.M.: Synthesis and characterization of high surface area nanosilica from rice husk ash by surfactant-free sol-gel method. J. Sol-Gel. Sci. Technol. 69, 465-472 (2014)

Ho, Y.S., McKay, G.: Pseudo-second order model for sorption processes. Process Biochem. 34, 451-465 (1999)

Karthik, R., Meenakshi, S.: Chemical modification of chitin with polypyrrole for the uptake of $\mathrm{Pb}$ (II) and $\mathrm{Cd}(\mathrm{II})$ ions. Int. J. Biol. Macromol. 78, 157-164 (2015a)

Karthik, R., Meenakshi, S.: Removal of $\mathrm{Pb}$ (II) and $\mathrm{Cd}$ (II) ions from aqueous solution using polyaniline grafted chitosan. Chem. Eng. J. 263, 168-177 (2015b)

Khan, N.A., Hasan, Z., Jhung, S.H.: Adsorptive removal of hazardous materials using metal-organic frameworks (MOFs): a review. J. Hazard. Mater. 244-245, 444-456 (2013)

Klapiszewski, T., Bartczak, P., Wysokowski, M., Jankowska, M., Kabat, K., Jesionowski, T.: Silica conjugated with kraft lignin and its use as a novel 'green' sorbent for hazardous metal ions removal. Chem. Eng. J. 260, 684-693 (2015) 
Kołodyńska, D., Wnętrzak, R., Leahy, J.J., Hayes, M.H.B., Kwapiński, W., Hubicki, Z.: Kinetic and adsorptive characterization of biochar in metal ions removal. Chem. Eng. J. 197, 295-305 (2012)

Kowalczyk, M., Kołodyńska, D., Hubicki, Z.: Modern hybrid sorbents: new ways of heavy metal removal from waters and wastewaters. Chem. Eng. Process. 70, 55-65 (2013)

Lagergren, S.: About the theory of so-called adsorption of soluble substances. Vetenskapsakad. Handl. 24, 1-39 (1898)

Lan, J., Lv, J., Zhang, W., Feng, J., Liu, Y., Wang, Z., Zhao, M.: Discrimation of types of thermal sensitive paper by characterization of the inorganic additives by Fourier Transform Infrared Microscopy, Confocal Raman Microscopy, and Scanning Electronic Microscope-Energy Dispersive Spectroscopy. Anal. Lett. 45, 2763-2773 (2012)

Langmuir, I.: The adsorption of gases on plane surfaces of glass, mica and platinum. J. Am. Chem. Soc. 40, 1361-1403 (1918)

Lee, S.M., Lalhmunsiama, Thanhmingliana, Tiwari, D.: Porous hybrid materials in the remediation of water contaminated with As(III) and As(V). Chem. Eng. J. 270, 496-507 (2015)

Li, Z-Ch., Fan, H.-T., Zhang, Y., Chen, M.-X., Yu, Z.-Y., Cao, X.-Q., Sun, T.: Cd(II)-imprinted polymer sorbents prepared by combination of surface imprinting technique with hydrothermal assisted sol-gel process for selective removal of cadmium(II) from aqueous solution. Chem. Eng. J. 171, 703-710 (2011)

Li, Z., Katsumi, T., Imaizumi, S., Tang, X., Inui, T.: Cd(II) adsorption on various adsorbents obtained from charred biomaterials. J. Hazard. Mater. 183, 410-420 (2010)

Li, X., Wang, Z., Li, Q., Ma, J., Zhu, M.: Preparation, characterization, and application of mesoporous silica-grafted graphene oxide for highly selective lead adsorption. Chem. Eng. J. 273, 630-637 (2015)

Madrakian, T., Afkhami, A., Rezvani-Jalal, N., Ahmadi, M.: Removal and preconcentration of lead(II), cadmium(II) and chromium(III) ions from wastewater samples using surface functionalized magnetite nanoparticles. J. Iran. Chem. Soc. 11, 489-498 (2014)

Mahmoud, M.E., Mohamed, R.H.A.: Biosorption and removal of $\mathrm{Cr}(\mathrm{VI})-\mathrm{Cr}(\mathrm{III})$ from water by eco-friendly gelatin biosorbent. J. Environ. Chem. Eng. 2, 715-722 (2014)

Mahmoud, M.E., Nabil, G.M., Mahmoud, S.M.E.: High performance nano-zirconium silicate adsorbent for efficient removal of copper(II), cadmium(II) and lead(II). J. Environ. Chem. Eng. 3, 1320-1328 (2015)

Mahmoud, M.E., Osman, M.M., Amer, M.E.: Selective pre-concentration and solid phase extraction of mercury(II) from natural water by silica gel-loaded dithizone phases. Anal. Chim. Acta 415, 33-40 (2000)

Maliyekkal, S.M., Lisha, K.P., Pradeep, T.: A novel cellulosemanganese oxide hybrid material by in situ soft chemical synthesis and its application for the removal of $\mathrm{Pb}(\mathrm{II})$ from water. J. Hazard. Mater. 181, 986-995 (2010)

Mortaheb, H.R., Zolfaghari, A., Mokhtarani, B., Amini, M.H., Mandanipour, V.: Study on removal of cadmium by hybrid liquid membrane process. J. Hazard. Mater. 177, 660-667 (2010)
Motlagh, M.M., Hassanzadeh-Tabrizi, S.A., Saffar-Teluri, A.: Sol-gel synthesis of $\mathrm{Mn}_{2} \mathrm{O}_{3} / \mathrm{Al}_{2} \mathrm{O}_{3} / \mathrm{SiO}_{2}$ hybrid nanocomposite and application for removal of organic dye. J. Sol-Gel. Sci. Technol. 73, 9-13 (2015)

Nguyen, T.C., Loganathan, P., Nguyen, T.V., Vigneswaran, S., Kandasamy, J., Naidu, R.: Simultaneous adsorption of Cd, Cr, $\mathrm{Cu}, \mathrm{Pb}$, and $\mathrm{Zn}$ by an iron-coated Australian zeolite in batch and fixed-bed column studies. Chem. Eng. J. 270, 393-404 (2015)

Peng, W., Xie, Z., Cheng, G., Shi, L., Zhang, Y.: Amino-functionalized adsorbent prepared by means of $\mathrm{Cu}$ (II) imprinted method and its selective removal of copper from aqueous solutions. J. Hazard. Mater. 294, 9-16 (2015)

Santhosh, C., Kollu, P., Felix, S., Velmurugan, V., Jeong, S.K., Grace, A.N.: $\mathrm{CoFe}_{2} \mathrm{O}_{4}$ and $\mathrm{NiFe}_{2} \mathrm{O}_{4} @$ graphene adsorbents for heavy metal ions-kinetic and thermodynamic analysis. RSC Adv. 5, 28965-28972 (2015)

Shafique, U., Anwar, J., Anzano, J.M., Salman, M.: Hazardous Metals: Sources, Toxicity, and Control, pp. 157-186. Nova Science Publisher Inc., New York (2011)

Soliman, E.M., Mahmoud, M.E., Ahmed, S.A.: Reactivity of thioglycolic acid physically and chemically bound to silica gel as new selective solid phase extractors for removal of heavy metal ions from natural water samples. Int. J. Environ. Anal. Chem. 82, 403-413 (2002)

Song, J., Kong, H., Jang, J.: Adsorption of heavy metal ions from aqueous solution by polyrhodanine-encapsulated magnetic nanoparticles. J. Colloid Interface Sci. 359, 505-511 (2011)

Sriprang, P., Wongnawa, S., Sirichote, O.: Amorphous titanium dioxide as an adsorbent for dye polluted water and its recyclability. J. Sol-Gel. Sci. Technol. 71, 86-95 (2014)

Viltuznik, B., Lobnik, A., Kosak, A.: The removal of $\mathrm{Hg}$ (II) ions from aqueous solutions by using thiol-functionalized cobalt ferrite magnetic nanoparticles. J. Sol-Gel. Sci. Technol. 74, 199-207 (2015)

Vishwas, M., Narasimha Rao, K., Arjuna Gowda, K.V., Chakradhard, R.P.S.: Optical, electrical and dielectric properties of $\mathrm{TiO}_{2}-\mathrm{SiO}_{2}$ films prepared by a cost effective sol-gel process. Spectrochim. Acta A 83, 614-617 (2011)

Wysokowski, M., Klapiszewski, Ł., Moszyński, D., Bartczak, P., Szatkowski, T., Majchrzak, I., Siwińska-Stefańska, K., Bazhenov, V.V., Jesionowski, T.: Modification of chitin with kraft lignin and development of new biosorbents for removal of cadmium(II) and nickel(II) ions. Mar. Drugs 12, 2245-2268 (2014)

Xiong, L., Chen, C., Chen, Q., Ni, J.: Adsorption of $\mathrm{Pb}(\mathrm{II})$ and $\mathrm{Cd}(\mathrm{II})$ from aqueous solutions using titanate nanotubes prepared via hydrothermal method. J. Hazard. Mater. 189, 741-748 (2011)

Zhao, J., Zhu, Y.-J., Wu, J., Zheng, J.-Q., Zhao, X.-Y., Lu, B.-Q., Chen, F.: Chitosan-coated mesoporous microspheres of calcium silicate hydrate: environmentally friendly synthesis and application as a highly efficient adsorbent for heavy metal ions. J. Colloid Interface Sci. 418, 208-215 (2014) 